\title{
MACHADO DE ASSIS, LEITOR DE HOMERO
}

\author{
Edson Ferreira Martins* \\ Recebido em: 09/03/2020
}

Aprovado em: 30/03/2020
* Professor Adjunto, Departamento de Letras, Universidade Federal de Viçosa. eferreiramartins@hotmail.com

RESUMO: No presente estudo, analiso a produção ficcional do escritor Machado de Assis relativa à década de 1870, quando o autor brasileiro, após ter-se dedicado à poesia e ao teatro, estreou no gênero romance, produzindo quatro obras no período: Ressurreição (1872), A mão e a luva (1874), Helena (1876) e Iaiá Garcia (1878). Focalizando o tema dos diálogos (Bakhtin, 2002 [1929]) que o autor estabelece em sua narrativa com as literaturas grega e romana produzidas na Antiguidade Clássica, objetivo demonstrar que, dentre os modelos destas matrizes que Machado versou continuadamente como autor-leitor, destaca-se o nome de Homero e os poemas épicos atribuídos a ele. Durante a análise das obras selecionadas, demonstro como a escolha das cenas homéricas imitadas, sobretudo da Ilíada, pelo futuro autor das Memórias Póstumas é importante para a construção de sua poética de revalorização da imitatio e da aemulatio que, aliada à sua visão aguda dos problemas sociais brasileiros, revoluciona a forma de se pensar o projeto de concepção de uma literatura nacional, em pleno contexto de ebulição do Romantismo, atravessando os limites desta escola e apontando saídas para a sua superação.

PALAVRAS-CHAVE: Machado de Assis; Recepção; Literaturas Clássicas; Homero; Ilíada; Odisseia.

\section{MACHADO DE ASSIS, HOMER'S READER}

\begin{abstract}
In this work, I analyze the fictional production of the writer Machado de Assis related to the decade of 1870, when the Brazilian author, after dedicating himself to poetry and theatre works, debuted in the genre of novels, producing four works in that period: Ressurreição (1872), A mão e a luva (1874), Helena (1876) and Iaiá Garcia (1878). Focusing on the theme of dialogues (Bakhtin, 2002 [1929]) that the author establishes in his narrative with the Greek and Roman literatures produced during the Classical Antiquity, I intend to show that, among the models
\end{abstract}


of these matrixes that Machado studied continuedly as an author-reader, the name of Homer and the epic poems imputed to him are highlighted. During the analysis of the selected works, I show how the choice of the homeric imitated scenes, mainly of the Iliad, by the future author of Memórias Póstumas is important to the construction of his poetics of revaluation of imitatio and aemulatio that, allied to his acute perception of the Brazilian social problems, revolutionize the way of thinking the project of creating a national literature, in a context of agitation of Romanticism, crossing over the limits of such school and indicating doorways to overcome it.

KEYWORDS: Machado de Assis; Reception; Classical Literatures; Homer; Iliad; Odyssey.

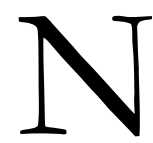

a biografia sucinta e excelente que nos dá Alfredo Bosi da vida de Machado de Assis, ao falar de sua paixão pela literatura, que pode ser observada nos hábitos incomuns de alguém que se revelou, desde os tempos de sua juventude até o fim de seus dias - quando ainda encontra fôlego para publicar, no ano de sua morte, o Memorial de Aires -, como um ávido leitor dos clássicos, escritos em diversas línguas e culturas, assim se expressa o crítico brasileiro:

Em poucos anos Joaquim Maria deu um salto qualitativo considerável, saindo do estreito ć́rculo familiar e aproximando-se de jornalistas, poetas e letrados que constituíam o meio cultural de uma cidade meio provinciana, meio europeizada, o Rio dos meados do século XIX. Esses tempos de primeira juventude foram marcados por intensos estudos solitários: sabe-se que Machado leu na biblioteca do Gabinete Português de Leitura, onde conviveu assiduamente com os clássicos vernáculos e os grandes nomes da literatura europeia, Dante, Tasso, Montaigne, Shakespeare, Cervantes, Molière, Pascal, Racine, Sterne, Goethe, Schiller, Lamartine, Byron, Heine, Musset, Victor Hugo, Herculano, Garrett... E os nossos Basílio da Gama, Gonzaga, Cláudio Manuel da Costa, Gonçalves Dias, Álvares de Azevedo... provavelmente, nenhum escritor brasileiro da segunda metade do século XIX pode ombrear-se com Machado em termos de memória literária vivida e aprofundada ao longo de anos de leitura ininterrupta (Bosi, 2011, p. 8).

Acredito que seja importante complementar esta antologia de autores europeus e brasileiros, esboçada por Alfredo Bosi, trazendo à tona também a importância do conhecimento que Machado teve de outros autores não citados nesta lista, que serviram eles próprios como modelo para a formação das literaturas europeias, sobretudo a partir do Humanismo. Autores oriundos da Antiguidade Clássica, os quais também Machado, no século XIX e num contexto de um Brasil pós-1822, versava diuturnamente durante o seu longo processo de formação de autor-leitor. Como tem demonstrado a crítica especializada das últimas três décadas, voltada para os diálogos machadianos com as diversas culturas e literaturas com as quais conversou, as relações dialógicas que o Bruxo estabeleceu com as 
literaturas grega e romana ${ }^{1}$ não podem mais ser ignoradas pelos estudos machadianos, se desejarmos compreender o que o autor do ensaio Instinto de Nacionalidade (1873) desejava propor quando afirmava ser possível ao verdadeiro escritor nacional falar "de assuntos remotos no tempo e no espaço" (Assis, 2006b [1873], p. 804). Como pretendo demonstrar neste texto, a Grécia - Homero em particular - situada num tempo ora mítico, ora histórico, mas entendida inescapavelmente como algo "antigo" ou "arcaico", fornecerá "assuntos" variados que o jovem romancista, escritor em formação, tomará para si, também como seus, apropriando-se deles, como homem de seu país, ao acrescentar seus haveres a este "pecúlio comum". ${ }^{2}$

Neste estudo, utilizarei como recorte o gênero romance, e me aterei, por questões de espaço, aos quatro primeiros livros deste gênero publicados por Machado, partindo da ideia de que a relação próxima com os clássicos antigos e modernos - que Bosi acertadamente aponta em Machado - não é mero preciosismo biográfico de um leitor amante da Literatura Universal, mas antes se constitui em uma marca fundamental para a construção de uma poética pessoal, de um autor e crítico literário que empreendeu, ainda em um momento de ebulição do Romantismo no Brasil, uma revalorização de dois procedimentos cultivados na tradição clássica ao longos de dois milênios, a imitatio e a aemulatio, posicionando-se contra o mito da originalidade romântica (proposto por autores literatos e de outras artes). Nascido em 1839, e desenvolvendo o seu gênio ao longo do século XIX, Machado atravessa a segunda metade do século não se filiando a nenhuma das escolas em disputa (tampouco será um realista, ou menos ainda um naturalista), podendo vivenciar estes momentos de transições estéticas, culturais e sociopolíticas, antecipando com suas experimentações no romance e no conto características da arte literária que seriam desenvolvidas por autores do século XX.

O que revela o diversificado universo citacional machadiano sobre gregos e romanos antigos, se observarmos os romances que publicou antes da revolução que causariam, interna e externamente a sua própria obra, as suas Memórias Póstumas, no lastro temporal que vai de 1872 - ano da publicação em livro de Ressurreição - a 1878, quando ele entrega aos leitores Iaiá Garcia? No seu romance inaugural, tematizando a infelicidade do sujeito, o protagonista, ironicamente denominado Félix, que não consegue confiar no amor de Lívia, e nos atendo apenas a autores citados textualmente (excetuando-se, portanto, a referência que Machado faz de mitos, deuses ou instituições culturais - como o Direito, as Artes ou a Filosofia - relacionados à Grécia e à Roma antigas), o autor faz menção a Platão e Esopo. Dois anos depois, em 1874, em $A$ mão e a lwva, romance que explora o lugar-comum dos conflitos amorosos em torno do ideal do casamento como um drama burguês, tecendo a trama de uma mão (Guiomar) que deve escolher a luva entre três cores (Estêvão, Jorge ou Luís Alves), enquanto esboça “o desenho de tais caracteres” (Assis, 2006a, p. 198), Machado

\footnotetext{
${ }^{1}$ Cf. os trabalhos de Rego (1989), Brandão (2000) e Martins (2015).

2 "Cada tempo tem o seu estilo. Mas estudar-lhes as formas mais apuradas da linguagem, desentranhar deles mil riquezas, que, à força de velhas se fazem novas, - não me parece que se deva desprezar. Nem tudo tinham os antigos, nem tudo têm os modernos; com haveres de uns e outros é que se enriquece o pecúlio comum" (Assis, 2006b, p. 809).
} 
amplia o seu flerte com os autores antigos, trazendo para seu texto conversas com César, Diógenes e Plutarco. Em Helena, romance que retoma já no nome a trágica e célebre heroína grega, o jovem romancista dobra a quantidade destes diálogos greco-romanos, e citará Aristófanes, Virgílio, Suetônio, Plutarco, outra vez César, Tertuliano e Santo Agostinho. Em 1878, e finalizando a sua primeira maneira de narrar, ${ }^{3}$ ao publicar Iaiá Garcia, Machado escolherá dialogar novamente com autores já folheados por ele, e que vão se tornando comuns em sua prosa de ficção: Diógenes, Virgílio e Plutarco. Entretanto, além dos autores que mencionei até aqui, há um outro, grego, que comparece em todos os quatro romances escritos por Machado, e não apenas quantitativamente, mas sobretudo qualitativamente quando referido/retomado: Homero. Nas seções seguintes, busco demonstrar onde e como Machado relê o autor a quem foram atribuídos os épicos do período arcaico, mimetizando seus motivos e léxicos, em sua produção ficcional da década de 1870, importantíssima para o seu reconhecimento como autor de prosa, tanto no romance como no conto, desejados pelo futuro autor de Dom Casmurro.

\section{ILÍADA}

Dentre os manuscritos da Ilíada existentes na Itália, existe um, atualmente depositado na Biblioteca Ambrosiana de Milão, que apresenta uma curiosidade literária interessante para pensarmos as formas de (re)leitura e de recepção da tradição clássica desde a ascensão do Humanismo nos finais da Idade Média, e em particular com a tradição helênica e escrita em grego. O manuscrito em questão, identificado como "Ambr. I 98 inf" pertenceu anteriormente ao poeta Francesco Petrarca. Porém, o célebre sonetista não sabia ler em grego, ainda que tardiamente tenha feito estudos da língua de Homero, seja como for, insuficientes para a leitura no original do poema que canta os rios de sangue e lágrima gregos e troianos.

No que tange à biografia de Machado de Assis, alguns paralelos são interessantes de serem traçados com a história vivida por Petrarca: o brasileiro também nunca esteve perto de dominar o grego, como o demonstrou Jean-Michel Massa, tendo feito no máximo alguns exercícios nesta língua quando já se encontrava na idade madura, o que inclui uma cópia de um texto original e de uma tradução de Xenofonte, hoje expostas no acervo museológico dedicado ao escritor na Academia Brasileira de Letras, exercícios de aprendiz a partir dos quais críticos de primeira água tentaram provar o multilinguismo de Machado, chamado por esta época de "o Homero brasileiro". Também sabemos, graças à curadoria de Massa, que a biblioteca pessoal de Machado de Assis continha os exemplares da Ilíada e da Odisseia, mas é importante observar que estas edições são traduções francesas, feitas por Leconte de

\footnotetext{
${ }^{3}$ Cf. o que diz Machado na Advertência ao leitor, de 1907: "Os trinta e tantos anos decorridos desta novela à reimpressão que ora se faz parece que explicam as diferenças de composição e de maneira do autor" (Assis, 2006a, p. 198, grifos nossos). Igualmente, também em 1907, veja-se o que diz o autor na nota à segunda edição de Helena: "Ele [o romance] é o mesmo da data em que o compus e imprimi, diverso do que o tempo me fez depois, correspondendo assim ao capítulo da história do meu espírito, naquele ano de 1876. [...] cada obra pertence a seu tempo" (Assis, 2006a, p. 272).
} 
Lisle. Nem é de se supor, eu acrescentaria, que Machado tirasse algum proveito da consulta de uma edição bilingue, grego/francês, existente em alguma livraria ou biblioteca pública na época em que escreveu seus primeiros quatro romances, pois, se Paris era a capital do século XIX, o francês era a sua langue de culture. Ora, se o francês ocupava este status no Oitocentos para europeus e brasileiros - o tempo de Machado -, Petrarca, por sua vez, distante cinco séculos dele, teve de encomendar a tradução da Ilíada para o latim, levada a cabo por Leôncio Pilato, para que pudesse ter acesso ao texto por si mesmo. Mas o que me parece importante salientar aqui é esta outra semelhança, maior, que une estes dois grandes escritores, ambos provenientes do mundo de duas línguas das culturas latinas: mesmo que separados por séculos, tendo vivido em épocas em que seguramente a circulação e a recepção dos textos homéricos terá se dado de formas diferentes por razões históricas e socioculturais, ${ }^{4}$ ambos veem a Ilíada como o primeiro poema, o livro das origens da literatura (primeiro grega, depois europeia, por fim ocidental), que os romanos utilizarão como modelo para seu comparativismo no período helenístico. Mas não só: Petrarca e Machado enxergam a Ilíada também como a tessitura inaugural da poiesis a partir da qual falou por primeiro a antiga Musa; ${ }^{5}$ ambos se entregam ao estudo mimético do poema arcaico ao qual, nos últimos três milênios, leitores-amantes e leitores-operários (oficiais do mesmo ofício de Homero), têm se debruçado como aprendizes diante deste canto épico, que continua a inspirar a imaginação de leitores, dos dois tipos, século XXI adentro.

\section{FÉliX OU O ANTI-AQUILES}

Comecemos nossa análise com a seguinte citação, encontrada nas páginas iniciais do romance Ressurreição (1872): "A carta de Meneses era cavalheiresca: descobria o estado de alma de Cecília e não hesitava em chamar ingrato ao prófugo dardânio. Félix sorriu lendo ambas as missivas; depois atirou-as a uma cesta e nunca mais as viu (Assis, 2006a, p. 125, grifos nossos).

Mas, para se mensurar a importância de Homero aos olhos e mãos atentas do jovem romancista, que completava ali 32 anos, talvez seja necessário observar mais atentamente o texto e notar que já no primeiro capítulo de seu primeiro romance Machado evocará o intertexto homérico como rito de passagem, de iniciação. De fato, a expressão que destacamos em itálico no trecho é interessante para se compreender como o autor constrói a reescrita

\footnotetext{
${ }^{4}$ As primeiras edições dos poemas homéricos, quando da redescoberta do autor no Ocidente datam apenas de finais do século XV (1488-1489). O surgimento da prensa móvel, aliado à tradução de seus textos para as línguas europeias a partir do século XVI, ainda que lentamente, proporcionarão condições de maior acesso aos textos da Ilíada e da Odisseia, escritos numa língua original cada vez mais de difícil acesso aos leitores. Sobre a recepção de Homero a partir deste período da "redescoberta", veja-se o estudo de André Malta (2012).

${ }^{5}$ Sobre os procedimentos de construção da arte poética grega no período arcaico, explorando-se os sentidos polissêmicos de arkhé como começo, princípio e poder, veja-se a discussão empreendida por Jacyntho Brandão em Antiga Musa: arqueologia da ficção (2015).
} 
de temas clássicos em sua narrativa. Na tradição grega arcaica, se relembrarmos o Canto II da Ilíada, Eneias surge como um dos líderes do exército troiano, convocado à guerra por Heitor e descrito nos seguintes termos:

[...] Muitos guerreiros, dos mais distinguidos, com eles as armas empunham, de a pugna encetar desejoso.

Sobre os Dardânios o mando exercia o nascido de Anquises e da divina Afrodite, o guerreiro notável Enéias, pós haver no Ida selvoso a um mortal uma deusa se unido. (Homero, Ilíada. II, 817-21, tradução de Carlos Alberto Nunes)

O qualificativo "Dardânio" recupera a genealogia de Eneias, que remonta a Dárdano, filho de Zeus e responsável pela mítica fundação de Troia. Na cultura romana, que recupera a tradição mítica grega e insere particularmente o mito de Eneias nos próprios mitos de fundação da Vrbs, Eneias retorna como o herói protagonista da Eneida, de Virgílio, épico do qual citamos a seguinte passagem, com menção ao adjetivo profugus:

Eu, que entoava na delgada avena

Rudes canções, e egresso das florestas,

Fiz que as vizinhas lavras contentassem

A avidez do colono, empresa grata

Aos aldeãos; de Marte ora as horríveis

Armas canto, e o varão que, lá de Tróia

Prófugo, à Itália e de Lavino às praias

Trouxe-o primeiro o fado $[\ldots]$

(Virgílio, Eneida, I, 1-7, tradução de Manuel Odorico Mendes)

Ao lado da referência patronímica, "dardânio", temos, na tessitura do romance de Machado de Assis, o adjetivo "prófugo". Está claro, para o leitor familiarizado com Homero e Virgílio, que estes qualificadores estão associados ao constante estado de fuga de Félix, o protagonista de Ressurreição - fuga essa que caracteriza toda a sua vida burguesa e amorosa, dada a incapacidade de Félix seja em firmar-se em um relacionamento, seja em dedicar-se ao trabalho, conforme esclarece o narrador onisciente. Detenhamo-nos, entretanto, um pouco mais no épico virgiliano: na narrativa desse poema, acompanhamos o perambular de Eneias, o prófugo dardânio, a cujo mito Machado alude. Eneias - o herói errante - surge aqui, numa leitura comparada, como uma alegoria para o coração errante de Félix, homem incapaz de afeiçoar-se verdadeiramente a uma mulher, comportamento que o opõe ao pio Eneias, homem de missão. A apropriação do mito, dessa forma, é feita por Machado destacando apenas a parte que lhe convém do mitema para sua (re)criação da fábula do herói: enquanto Eneias vaga pelo mundo, após a destruição de sua terra natal (Troia), em busca de cumprir o destino traçado pelos deuses (fundar Roma), Félix, por sua vez, adota voluntariamente o papel de nômade narcisístico, indo de relacionamento em relacionamento sem nunca se prender a ninguém, um fugitivo de si mesmo, que se contenta com amores primaveris e teme pelo fim agourento de cada jornada. Não há missão, nem crescimento do herói protagonista: Félix 
jamais ressurgirá de nada. O leitor (e a leitora) deverão aceitar esta verdade ao final do livro, ou se sentirão melancolicamente desolados pelo anticlímax que domina a trama costurada pelo autor deste romance.

A fim de se compreender melhor a análise proposta para o diálogo com a matriz greco-romana, seria interessante uma leitura cruzada dos gêneros cultivados por Machado, que, mais tarde, anotará o seguinte pensamento em uma crônica sua, de 1877, recolhida em História de 15 dias: "Cada tempo tem a sua Ilíada; as várias Ilíadas formam a epopeia do espírito humano" (Assis, 2006b, p. 358). Neste sentido, o jovem Machado, na persona do crítico literário, propõe que o discurso mítico-heroico se constrói de formas diferentes ao longo das eras: Eneias, de estirpe real, um dos personagens importantes que povoam a galeria da Ilíada, assume, séculos depois, o lugar de pai da pátria, prefigurando Augusto na Eneida, para, noutro momento, noutra literatura, influenciada pela tradição clássica por meio da imitatio, despontar no romance inaugural de Machadinho, ${ }^{6}$ um autor-operário (Rocha, 2013), nesta fase de sua vasta produção ficcional. O mais importante a assinalar neste gesto inaugural da citação de temas clássicos em seus romances me parece ser o seguinte: ao construir o personagem Félix como o "prófugo dardânio", Machado não apenas reescreve o mito, mas, valendo-se da imitação de Homero (mediada ainda pela recepção/emulação de Homero por Virgílio), também começa um procedimento narrativo que vise, em logrando favor da crítica do público leitor, a inserção de seu nome entre os reconhecidos como os grandes autores da literatura ocidental. Simultaneamente, ao mesmo tempo em que lança a pedra angular de seu projeto com este primeiro romance, ele renova a literatura brasileira, tecendo uma nova configuração para o tipo de herói, mais verossímil ao Brasil oitocentista do Segundo Reinado. Do ponto de vista das relações entre textos, vale a pena reverberar o que afirma Fiorin, ao discutir o pensamento bakhtiniano: "O primeiro conceito de dialogismo diz respeito, pois, ao modo de funcionamento real da linguagem: todos os enunciados constituem-se a partir de outros" (Fiorin, 2008, p. 30). Assim sendo, podemos compreender o papel orgânico da linguagem no discurso literário: não há escrita que esteja imune à influência de outrem. Toda narrativa constrói-se a partir de narrativas outras, uma vez que a própria linguagem, como nos lembra Bakhtin (2002), é perpassada pelo discurso alheio em várias instâncias. Toda obra literária remete a outras obras, àquelas que a precederam e fundamentaram, direta ou indiretamente. Não seria diferente no romance machadiano, dado que o Bruxo maximizará, ao longo de sua produção da década de 1870, um exercício constante, cada vez mais enciclopédico e embebido na sátira, de reescrita literária por meio ora da estilização, ora da paródia que promove dos clássicos antigos (e contemporâneos), conforme se percebe, por exemplo, nas relações entrelaçadas por ele partindo do mito de Eneias para chegar à composição psicológica do personagem Félix.

Continuando nossa análise, leiamos outro trecho do romance em que o texto homérico é novamente retomado pelo narrador:

\footnotetext{
${ }^{6}$ Forma pela qual Augusto Meyer se refere ao autor, objetivando mensurar a qualidade da narrativa machadiana antes da revolução formal promovida pela publicação das Memórias Póstumas de Brás Cubas (cf. Meyer, 2006).
} 
Duas faces tinha o seu espírito, e conquanto formassem um só rosto, eram todavia diversas entre si, uma natural e espontânea, outra calculada e sistemática. Ambas, porém, se mesclavam de modo que era difícil discriminá-las e defini-las. Naquele homem feito de sinceridade e afetação tudo se confundia e baralhava. Um jornalista do tempo, seu amigo, costumava compará-la ao escudo de Aquiles - mescla de estanho e ouro, - "muito menos sólido", acrescentava ele. (Assis, 2006a, p. 118)

A menção ao escudo de Aquiles, outra referência à Ilíada, aparece aqui usada como forma de demarcar a complexa personalidade de Félix. A menção do poeta ao referido escudo surge em um momento crítico vivido pelo herói. Após a morte de Pátroclo, a armadura de Aquiles, que o jovem guerreiro furtivamente vestia, é levada por seu assassino, Heitor. Consumido pela culpa e pela dor, causada pela morte do amigo querido, Aquiles é acudido por sua mãe, Tétis, que pressente o profundo sofrimento do filho. Ao anseio inicial do herói por glória, soma-se agora o desejo de vingança, manifesto pela ira. Tétis, então, promete ao filho novas armas, e vai ao Olimpo pedir a Hefesto que forje um escudo e um elmo para Aquiles, ao que o deus atende. Homero oferece uma descrição pormenorizada da feitura do famoso escudo. ${ }^{7} \mathrm{Na}$ cena, podemos perceber menções específicas ao material usado na produção do escudo - mais especificamente, metais usados na confecção de armaduras e armas. A dicotomia entre estanho e ouro, materiais diferentes que são combinados de modo a formar um único objeto, assim como "sinceridade e afetação" perfazem a compleição de Félix, homem cuja personalidade poderia ser caracterizada como dual, não fosse o fato de que se mesclam e se tornam indistinguíveis, sem que se possa definir onde começa uma coisa e termina a outra. Essa referência feita pelo narrador mescla a estilização da fonte grega (Ilíada/Homero) e a paródia do tipo de herói (Aquiles/Félix), delineando um pouco mais a personalidade do protagonista do romance, compreendido cada vez mais como um homem consumido por incertezas. Félix, no entanto, ao contrário do escudo de Aquiles, é "muito menos sólido". Um sujeito de vontades confusas e intenções desconhecidas, o que consequentemente contribui para a sua pouca percepção acerca do amor - conflito que move o aparentemente imóvel romance. Nesse sentido, o nome do personagem traz em si a piscadela do autor, que espera que o "fino leitor" reconheça as operações de deslocamento do

\footnotetext{
7 "Deixa-a, depois de falar, dirigindo-se para os seus foles,/ que pôs no fogo, ordenando que logo o trabalho iniciassem./ Vinte eram eles ao todo, e em fornalhas também de igual número./ Logo se põem a soprar por maneira contínua e variável/ com mais vigor, quando Hefesto animado ficava; mais lentos, / quando o que queria o ferreiro, ou o trabalho dessa arte o exigia./ Bronze infrangível não cessa de ao fogo lançar, duro estanho,/ ouro de grande valor e, também, muita prata. Em seguida,/ pôs sobre o cepo a maior das incudes, e o malho pesado/ numa das mãos, sustentando, a tenaz na outra, firme, segura./ Grande maciço, primeiro, fabrica o admirável escudo,/ com muito esmero, lançando-lhe à volta orla tríplice e clara,/ de imenso brilho. De prata, a seguir, fez o bálteo vistoso./ Cinco camadas o escudo possuía, gravando na externa/ o hábil artífice muitas figuras de excelso traçado" (Homero, Ilíada, XVIII, 468-82, tradução de Carlos Alberto Nunes).
} 
texto original homérico por meio da ironia com a qual batiza o desafortunado protagonista de Ressurreição.

\section{Cada tempo tem sua a sua Troia}

Em $A$ mão e luva, observamos a repetição do método composicional. Machado outra vez citará Homero nas páginas iniciais de seu romance. Vejamos como.

Em uma sequência de mitemas que aludem ao poema da Guerra de Troia, a narrativa machadiana se desdobra em um rol de citações, dessa vez com ênfase na caracterização psicológica do personagem Estevão, um dos pretendentes à mão de Guiomar, a heroína do romance. O lugar elegido por Machado para a construção dessa parte da narrativa é o teatro, sempre repleto de gente, acontecimento social e cultural de grande relevo para as elites no Rio de Janeiro daquela época:

A corte divertia-se, apesar dos recentes estragos do cólera -; bailavase, cantava-se, passeava-se, ia-se ao teatro. O Cassino abria os seus salões, como os abria o Clube, como os abria o Congresso, todos três fluminenses no nome e na alma. Eram os tempos homéricos do teatro lírico, a quadra memorável daquelas lutas e rivalidades renovadas em cada semestre, talvez por um excesso de ardor e entusiasmo, que o tempo diminuiu, ou transferiu,-Deus lhe perdoe, - a cousas de menor tomo. (Assis, 2006a, p. 204)

A expressão "tempos homéricos do teatro lírico" requer atenção. Em princípio, ela poderia ser interpretada, com a ressemantização do adjetivo "homérico", no sentido de algo como "eram os tempos de uma época grandiosa para o teatro lírico", um período em que todos frequentavam as óperas com suas atrizes belas a causar paixões na plateia. É preciso observar, entretanto, que Machado, no mesmo trecho, linhas abaixo, faz em sequência três outras referências ao poema épico grego, cujos intertextos naturalmente são reconhecíveis apenas pelo leitor familiarizado com Homero. Juntos, esses três mitemas compõem o cenário de verossimilhança criado por Machado no qual contracenam o personagem ultrarromântico e fictício Estevão e alguns personagens reais do Rio oitocentista, como as atrizes Lagrua e Charton. O trecho seguinte, continuação natural do anteriormente citado, traz a descrição desse cenário social efervescente da capital do Império em meados do século XIX:

Quem se não lembra, - ou quem não ouviu falar das batalhas feridas naquela clássica plateia do Campo da Aclamação, entre a legião casalônica e a falange chartônica, mas sobretudo entre esta e o regimento lagruísta? Eram batalhas campais, com tropas frescas, - e maduras também, - apercebidas de flores, de versos, de coroas, e até de estalinhos.

Uma noite a ação travou-se entre o campo lagruísta e o campo chartonista, com tal violência, que parecia uma página da Ilíada. Desta vez, a Vênus da situação saiu ferida do combate; um estalo 
rebentara no rosto da Charton. O furor, o delírio, a confusão foram indescritíveis; o aplauso e a pateada deram-se as mãos, - e os pés. A peleja passou aos jornais. "Vergonha eterna (dizia um) aos cavalheiros que cuspiram na face de uma dama!"

- "Se for mister (replicava outro) daremos os nomes dos aristarcos que no saguão do teatro juraram desfeitear Mlle. Lagrua."

- "Patuléia desenfreada!"

- "Fidalguice balofa!"

Os que escaparam daquelas guerras de alecrim e manjerona hão de sentir hoje, após dezoito anos, que despendera excessivo entusiasmo em coisas que pediam repouso de espírito e lição de gosto.

Estêvão é uma das relíquias daquela Tróia, e foi um dos mais fervorosos lagruístas, antes e depois do grau. A causa principal das suas preferências, era decerto o talento da cantora; mas a que eles costumavam dar, nas horas de bom humor, que eram todas as vinte e quatro do dia, tirantes as do sono, essa causa que mais que tudo o ligava aos "arraiais do bom gosto" dizia ele, era, - imaginem lá, - era o buço de Mlle. Lagrua. (Assis, 2006a, p. 204-5)

A intertextualidade com o texto homérico é patente, pelo léxico de matiz bélico utilizado pelo narrador. Entretanto, o deslocamento espacial (da Grécia micênica para a capital do Império luso-brasileiro) e cronológico (dos séculos XII-VIII a.C. para o século XIX) são aproveitados com maestria por Machado para criar um efeito de humor, ao comparar uma página do poema-símbolo da guerra (A Ilíada) com a narrativa deste outro "combate" - que nada tem de épico - travado no "Campo da Aclamação", a despeito das "batalhas", "legiões" e "falanges" ali observadas. A paródia ganha contornos definitivos com a citação do mitema da cidadela de Troia, que, em vez de ter as "relíquias" nobres e virtuosas da altura de um Heitor, de um Príamo ou de um Eneias, figuras típicas do herói épico da Antiguidade, passa a ser defendida pelo apaixonado e atabalhoado Estêvão, "uma das relíquias daquela Tróia" - e eu acrescentaria, uma relíquia de tamanho fluminense - na visão sarcástica do narrador machadiano. Parafraseando o título de seu romance, Machado utiliza as suas mãos de ficcionista para executar, com plasticidade e num estilo elegante de prosa fluida, o que ele mesmo propusera com as mãos de crítico que visava reformar a arte literária nacional: ser homem de seu tempo e de seu país (apontando suas contradições políticas, sociais, econômicas), por meio da leitura semiótica do mundo operacionalizada pela literatura, nomeadamente aqui por meio da imitação de um grande autor: Homero.

Por fim, e terminando os intertextos com Homero em seu segundo romance, o narrador compara a atriz de teatro lírico Charton Demeur a Vênus/Afrodite. Nesse ponto, Machado alude a uma passagem da Ilíada (V, 330-42), em que o poeta descreve um dos episódios bélicos da contenda entre gregos e troianos: a perseguição de Diomedes à deusa do amor, que, ainda que fazendo pulsar o sangue dos amantes, foi sempre descrita no Panteão grego como "sem força" para as artes marciais. Comparada em beleza à Vênus homérica, a atriz Charton também "saiu ferida do combate", mas, na verdade, por levar, dentro da 
confusão, "um estalo", isto é, uma bofetada no rosto. Machado, ao comparar os dois episódios, parodia o tema tratado, relendo Homero e compondo, a seu modo, o novo "épico", a nova Ilíada, de seu tempo, que elege o romance como gênero privilegiado para a narrativa da nova configuração do herói moderno. O tom mais levemente irônico, comparando-se com o campo de batalhas reais travadas entre os deuses olímpicos em auxilio a heróis antigos, é uma diferença saliente na forma de apropriação do discurso homérico e de ressignificação destes mitemas greco-romanos, incorporados sistematicamente em seus romances, como um mosaico de citações, consoante o viés delineado para a releitura do clássico proposto em cada cena pelo autor.

\section{Da Helena grega à Helena fluminense}

Dando sequência ao seu projeto romanesco, a escolha do nome da personagem principal não poderia ser melhor pensada por um autor como Machado, que desejava estabelecer uma poética da emulação com as matrizes antigas da tradição literária ocidental. Em sua gênese, a homônima da heroína machadiana é aquela ${ }^{8}$ por quem - segundo as origens da literatura grega - milhares de homens desceram ao Hades, perecendo por vontade da implacável Moira no longo cerco grego à cidadela de Troia, a fim de resgatar a esposa de Menelau, raptada pelo sedutor príncipe troiano Páris. Nesse sentido, entendemos que uma leitura cruzada do terceiro romance de Machado que leve em conta a recepção do mito da Helena espartana pode evocar novos sentidos a partir dos ecos do trágico que Machado estiliza ao construir a rede de relações entre as duas Helenas, cuja semelhança vai muito além da simples confluência do nome. Comecemos, então, a traçar esses pontos de convergência entre as personagens.

$\mathrm{Na}$ cultura grega, a personagem Helena, entre outras fontes arcaicas citada por Homero, era filha de Zeus e Leda, mas seu pai humano era Tíndaro. Note-se que a personagem machadiana homônima possuía como mãe Ângela, e também dois pais, o Conselheiro Vale

\footnotetext{
${ }^{8}$ No que se refere à lenda de Helena, avaliando a recepção do épico no trágico antigo, Grimal aponta a complexidade dos mitos que envolviam essa personagem. Observa o estudioso que, na versão de Eurípides, ao voltar de Troia, antes de regressar definitivamente a Esparta, o casal Helena-Menelau vai visitar Agamêmnon em Argos, precisamente no dia em que Orestes tinha matado Clitemnestra e Egisto, assassinos do irmão de Menelau. Ao ver Helena, descrita na peça do tragediógrafo com fasto oriental à moda troiana, Orestes, tomado pela cólera e julgando-a responsável por todos os infortúnios sofridos por sua família, tenta matá-la: “[...] Por ordem de Zeus, porém, Apolo raptou-a e tornou-a imortal. Esta lenda não está conforme à tradição mais corrente que, após a Odisseia, mostra Helena regressando a Esparta juntamente com Menelau e sendo exemplo de todas as virtudes domésticas. No entanto, a lenda da divinização de Helena conservava alguma autoridade, uma vez que se conhecia grande número de santuários a ela consagrados, nos quais se honrava também Menelau. Este teria sido divinizado a pedido de Helena, que pretendia dar-lhe alguma compensação dos tormentos que lhe infligira em vida" (Grimal, 2005, verb. Helena, p. 199-200).

${ }^{9}$ Sobre este assunto, recomendamos a leitura do ensaio de Maria Cecília Coelho, Helena, Eurípides e Machado de Assis (2002).
} 
e Salvador. Analisando-se a transposição das lendas gregas para o texto machadiano, do épico ao romance, temos a conversão do grandioso Zeus na figura socialmente influente do conselheiro, ao passo que o herói espartano Tíndaro teria o seu duplo no humilde pai biológico de Helena, ironicamente denominado Salvador. No tocante às repentinas mudanças na vida social, observe-se que uma não foi bem-aceita em Troia, enfrentando desconfianças e dificuldades de adaptação (cf. Odisseia, III, 133-139), sentimentos experimentados também pela outra, que sofre ao ser colocada no seio da aristocrática família dos Vale, tendo sua presença contestada por alguns membros que frequentavam aquele nicho burguês (cf. Assis, 2006a, p. 286).

A beleza física inigualável da Helena grega será estilizada também no diálogo intertextual que Machado estabelece com a tradição da Antiguidade. Se a personagem homérica era "então a mulher mais bela do mundo e exemplo de todas as virtudes domésticas" (Grimal, 2005, p. 198), a machadiana, por sua vez, era dócil, afável e inteligente, possuindo "a arte de acomodar-se às circunstâncias do momento" (cf. Assis, 2006a, p. 286).

Essas "virtudes domésticas e maneiras elegantes", que conviviam harmoniosamente em Helena, só tinham sentido em uma sociedade cuja moral valorizasse um modo de vida cortês, exatamente o meio social descrito pelos romances de Machado, ambientados no Rio de Janeiro urbano do Oitocentos. Nesse ponto, nos parece que o Bruxo irá adaptar mais um excerto do mito da Helena espartana à composição da sua. Como já salientamos, a Helena grega foi o motivo de uma das maiores guerras da Antiguidade Clássica, a guerra de Troia, que, conforme salienta Brandão (2012), tem sua gênese em um juramento feito entre os pretendentes da belíssima moça de defender a honra do escolhido por ela:

Quando uma verdadeira multidão de pretendentes à mão de Helena assediava a princesa, Tíndaro, a conselho do solerte Ulisses, ligou-os por dois juramentos: respeitar a decisão de Helena na escolha do noivo, sem contestar a posse da jovem esposa e se o escolhido fosse, de qualquer forma, atacado, os demais deviam socorrê-lo. (Brandão, 2012, p. 90)

Ora, assim como o pacto selado entre os pretendentes à mão da mais bela mulher da Hélade, o qual garantia a segurança do escolhido como esposo pela princesa, o testamento deixado pelo Conselheiro Vale traria a mesma sensação de segurança econômica e moral ao futuro marido da jovem e bela Helena - alçada socialmente à condição de "princesa" após esse fato jurídico. Tal pacto, entretanto, fora dos contornos aristocráticos do mundo grego arcaico, se dá nos termos da complexa rede socioeconômica do Brasil do Segundo Reinado, segundo os quais o conselheiro dita as normas aos demais membros de sua família. Nesses termos, na figura do paterfamilias, decide ele unilateralmente pela proteção de Helena e - por que não o dizer? - indiretamente também de seu futuro "escolhido", garantia das credenciais que o nome Vale possuía (mais uma vez a onomástica machadiana fala por si), dada a herança material que a jovem asseguraria com a adoção oficializada.

Dando sequência à reescrita dos mitos gregos em seu romance, Machado se reportará ao episódio do rapto da Helena espartana. A tradição mítica, em sua versão mais conhecida, 
entrecruza a história da seguinte maneira: quando Afrodite garantiu a Páris o amor da mais bela mulher do mundo, após este declará-la possuidora da maior beleza entre as deusas presentes no casamento de Peleu e Tétis, o príncipe troiano estava desde então destinado ao amor da esposa de Menelau. Segundo Brandão (2012, p. 113), “da cidadela de Ílion, em companhia de Eneias, partiu Alexandre para Esparta, em busca de Helena”. Aí foi recebido por Menelau, mas o rei de Esparta precisou viajar a fim de prestar homenagens a um parente falecido; em seguida, entregou os hóspedes aos cuidados da esposa, que, apaixonada, reuniu todos os tesouros que pôde e fugiu com Páris, deixando em Esparta sua filha Hermíone, ainda uma criança; quando o príncipe Páris Alexandre raptou Helena, Menelau, a quem ela escolhera por marido, pediu auxílio a seu irmão Agamêmnon, o poderoso rei de Micenas, que também estava ligado a Menelau por juramento. Agamêmnon foi escolhido comandante supremo da armada aqueia, seja por seu valor pessoal, seja porque era uma espécie de rei suserano, dada a importância de Micenas no conjunto do mundo aqueu, quer por efeito de hábil campanha política. Convocados os demais reis ligados por juramento a Menelau, formou-se o núcleo da grande armada destinada a vingar o rapto de Helena e atacar Troia, para onde Páris levara a princesa (Brandão, 2012, p. 90-1).

No encadeamento dos mitos relativos à guerra de Troia, a carga de tragicidade da história entre gregos e troianos começa com o gesto inaugural do rapto de Helena, prometida a Páris por Afrodite. Esse episódio em particular - o gesto do rapto -, conforme dele falam diferentes versões dos mitos gregos antigos em torno da personagem, vai ser revisitado por Machado em dois momentos particulares de seu romance. No primeiro deles, temos não um rapto em si, mas o seu planejamento. Mendonça, amigo de Estácio que estava enamorado de Helena, pondera as (des)vantagens de pedir ou não sua mão, pois “dever a esposa à evocação do nome do conselheiro equivalia a um rapto” (Assis, 2006b, p. 349). Machado se vale do mesmo substantivo, "rapto", abstratizando, porém, em seu romance o que era concreto no mito antigo, dado que Mendonça tem receio de raptar o sobrenome, e não propriamente Helena. Mais à frente, no mesmo capítulo, Estácio, em conversa com a irmã, tratando da decisão de ela casar-se ou não com Mendonça, indaga em tom de ciúme: "a tua felicidade exige que esse homem venha cá, que te cases com ele, que nos fujas?” (Assis, 2006b, p. 350). Pela estilização dos mitos gregos, tanto a ideia do rapto quanto a da fuga permeiam a expectativa do leitor conhecedor de Homero nesse ponto do romance, a partir das operações miméticas criadas pelo narrador machadiano. Contudo, Machado inverterá a lógica de ação da sua Helena em contraste com a espartana ao apresentar o desenlace da história: a Helena machadiana não só não foge com um amante, como não se casa com ninguém, ainda que padeça de amores por um certo homem (o irmão); além disso, revelado o segredo de sua paternidade, sua origem humilde, tudo corroborará para o desencadeamento de sua tragédia pessoal, envolvida pela vergonha da suspeita alheia sobre seus reais interesses junto à família Vale, o que culminará em sua depressão e, finalmente, em sua morte. No diálogo intertextual, não há só presenças, mas também estratégias de silenciamento: o romancista afasta-se aqui de alguns episódios fundamentais da história da Helena espartana, que foge, se casa, usurpa alguns bens e desencadeia uma série de tragédias. Machado, portanto, subverte em parte o 
sentido do mito grego, propondo o desfecho em outra direção: o do sufocamento moral e subsequente morte da inocente Helena por uma sociedade patriarcal, que encontra agentes determinados a impedir a ascensão social dos membros das camadas menos abastadas, tal como agem dentro do romance a fria D. Úrsula, o amargo Dr. Camargo, para o que não deixa de corroborar o espírito do indeciso Estácio.

\section{ValÉRIa ou a ANTI-TÉtis}

Em seu enredo, o quarto romance de Machado de Assis, Iaiá Garcia, contém também, em chave parodística, a reescrita de um episódio célebre presente no canto I da Ilíada (v. 348-530). Lamuriosa por saber que é certa a morte do filho na duríssima guerra (que duraria longos dez anos), Tétis é procurada por Aquiles, que lhe pede intervenção junto a Zeus Cronida, rogando ao deus supremo que os aqueus fossem punidos pela soberba de Agamêmnon, que o havia humilhado, tomando-lhe seu prêmio de guerra (Briseida). Tétis, por sua vez, vendo o sofrimento do filho, apieda-se da sua súplica. Dirige-se ao Olimpo e barganha com Zeus nos seguintes termos: se é certo que seu filho teria uma vida curta, cumprindo seu fado através da guerra, que em troca seu nome alcançasse honra e glória eternas. Ora, no romance de Machado, Valéria, a mãe de Jorge, em princípio comunga com Tétis o verdadeiro amor maternal, pois parece agir de forma semelhante à titânide, já que planeja enviá-lo para a Guerra do Paraguai. Entretanto, o narrador machadiano nos revela um segredo terrível da alma de Valéria, perscrutando-lhe a forma de manifestar este "amor": na verdade, Valéria prefere até mesmo a possível morte de seu filho a vê-lo envolto no manto, para ela vergonhoso, de um casamento com uma coitada qualquer, como Estela:

- Jorge está formado, disse ela; mas não tem queda para a profissão de advogado nem para a de juiz. Goza por enquanto a vida; mas os dias passam, e a ociosidade faz-se natureza com o tempo. Eu quisera dar-lhe um nome ilustre. Se for para a guerra, poderá voltar coronel, tomar gosto às armas, segui-las e honrar assim o nome de seu pai. - Bem; mas vejamos outra consideração. Se ele morrer? Valéria empalideceu e esteve alguns minutos calada, enquanto Luís Garcia olhava para ela, a ver se lhe adivinhava o trabalho interior da reflexão, esquecendo que a idéia de um desastre possível devia ter-lhe acudido, desde muito, e se não recuara diante dela, é porque a resolução era inabalável. - Pensei na morte, disse Valéria daí a pouco; e, na verdade, antes a obscuridade de meu filho que um desastre... mas repeli essa idéia. A consideração superior de que lhe falei deve vencer qualquer outra. (Assis, 2006a, p. 400)

O sarcasmo do narrador machadiano mostra-se também na gradação com que nos apresenta as armas com que Valéria tentou separar os dois corações (Estela e Jorge): o aconselhamento materno-burguês principia com o apelo do amor ao decoro de classe; à oferta de uma viagem à Europa; para terminar, enfim, com a ideia do alistamento militar do 
filho único. Em tom de galhofa, assim se manifesta Machado (autor, não esqueçamos, em vias de publicar as suas desabusadas Memórias Póstumas), ao concluir o episódio da querela entre a vontade de Valéria (uma Tétis sui generis) e a de seu diminuto Aquiles fluminense: "Assim foi que de um incidente, comparativamente mínimo, resultara aquele desfecho grave, e de um caso doméstico saía uma ação patriótica” (Assis, 2006a, p. 415).

No que tange à personagem Iaiá Garcia, filha de Luís Garcia, é construída por Machado com valores morais que visam angariar grande empatia do leitor. Demonstra um dedicado amor filial (pietas), ao mesmo tempo que é altiva, sempre reagindo às situações à sua volta, no limitado nicho familiar em que cresce, com graça, desenvoltura e independência. Mesmo no desabrochar do amor por Jorge, é cuidadosa ao demonstrá-lo, estando muito longe dos excessos típicos das personagens românticas. Em uma cena bucólica da narrativa, Machado também se valerá de elementos clássicos para descrever a beleza física e a pureza d'alma características da menina:

Na chácara havia um canteiro circular, plantado de grama, no centro do qual jorrava a água de um repuxo. A bacia deste era orlada de plantas, cujas folhas largas, rajadas umas de escarlate, outras de branco, interrompiam a monotonia da relva. Dessas folhas colhera Estela algumas, entretecera os talos formando uma capela, a pedido de Iaiá. Quando Luís Garcia chegou à janela, a moça concluía o difícil trabalho. Uma vez pronto, Iaiá, que olhava para ela, infantilmente ansiosa, inclinou a cabeça, e Estela cingiu-a com a grinalda rústica; depois recuou alguns passos, aproximou-se outra vez, concertou-a melhor. As folhas caíam-lhe sobre os ombros irregularmente, ou erguiam-se sobre a cabeça, e o todo daria idéia de uma náiade casquilha. (Assis, 2006a, p. 430)

A despeito da condição modesta do lugar onde habitavam, sem os luxos dos jardins aristocráticos, Machado cria um cenário típico do habitat das ninfas da mitologia grega, em cujo centro "jorrava a água” e no qual gravita a figura luminosa de Iaiá, descrita idealmente como uma náiade. A raiz grega desse nome, Naís, está semanticamente ligada ao ato de nadar, sendo, portanto, as náiades ninfas aquáticas. Portadoras de dons, como a cura e a profecia, exercem certo controle sobre a água, punindo os infratores de suas águas com doenças ou até mesmo a loucura, apossando-se por vingança de seus corpos (Grimal, 2005, p. 3212). Entretanto, nessa cena, a parte constitutiva de sua mitologia que interessa ao recorte machadiano para a composição de Iaiá se refere à beleza física que as náiades exalavam, com voz doce e um ar que transpirava leveza. Eis como opera aqui, em linhas gerais, o processo da recepção de um tema clássico pelas lentes machadianas. Envolvendo a "náiade" Iaiá, o romance retoma outra narrativa da Grécia arcaica, numa nova passagem da Ilíada: "Homero conta que Vênus, descendo ao campo da batalha entre gregos e troianos, saiu dali ferida e ensanguentada. Iaiá teve a sorte da diva homérica; interpondo-se entre Jorge e Estela trouxe dali ferido o coração. (Assis, 2006a, p. 487) 
Conforme já assinalamos, não é a primeira vez que Machado incorpora a cena da Vênus ferida em combate em seus romances, pelo que demonstra ter uma predileção por ela e seus temas, tendo nela se apoiado para falar de gritarias e cusparadas havidas entre os fãs acalorados de duas cantoras de ópera no teatro. Em Iaiá Garcia, a cena homérica se passa logo após Jorge e Iaiá revelarem um ao outro que se amavam, em uma confissão silenciosa e comedida, sem excesso sentimental. Como observa Guimarães (2012, p. 149), “em Iaiá Garcia, os desencontros e frustrações vão se multiplicando no desenrolar da narrativa, sem jamais atingir um clímax e sem produzir cenas de extravasamento emocional". Entretanto, mesmo após essa mútua revelação, Iaiá guarda em seu íntimo uma hesitação quanto aos sentimentos de Jorge por Estela, sem saber se a paixão anterior fora vencida. Jovem ainda, projetando uma rival, a filha de Luís Garcia se aflige. Neste caso, o diálogo tecido com a Ilíada se constitui como uma estilização, uma vez que o romance reafirma a situação de Vênus pela paridade entre o ferimento da deusa durante a Guerra de Troia e a insegurança e o sofrimento de Iaiá, originados pelo sentimento amoroso por Jorge e pelo ciúme de Estela. Retomando os versos do poema homérico, é possível perceber melhor a similaridade entre os textos, os quais guiam a estilização machadiana:
[...] A Cípria, com bronze impiedoso, era seguida por este, ${ }^{10}$ que vira ser deusa indefesa, bem diferente das outras que os prélios dos homens frequentam, tal como Palas Atena ou Enió, eversora de muros. Quando, afinal, a alcançou pelo meio dos fortes guerreiros, pula o magnânimo filho do grande Tideu para a frente, e a extremidade da mão delicada, com a lança pontuda, fere de leve. Foi fácil ao bronze riscar a epiderme, pós ter o manto divino, que as Graças teceram, rasgado, junto ao punho. Escorreu logo, o icor imortal da deidade, sangue que corre nas veias de todos os deuses eternos.
Não se alimentam de pão, roxo vinho não bebem; por isso sangue não têm, como os homens, que deuses eternos lhe chamam. (Homero, Ilíada, V, 330-42, tradução de Carlos Alberto Nunes)

A passagem remete ao momento em que Afrodite, descendo ao campo de batalha para proteger seu filho Eneias e afastá-lo do perigo, é ferida e atemorizada por Diomedes. A deusa afastou-se e foi levada por Íris, sentindo dor e medo. Iaiá Garcia, por sua vez, a Vênus machadiana, posicionou-se diante de seu combate (um conflito doméstico) e também foi tomada por esses dois sentimentos. Desejando ser a barreira entre o passado de Jorge e Estela, a jovem foi novamente surpreendida pela incerteza, insinuada pelo veneno maledicente de Procópio Dias, interessado em macular o amor nascente entre Jorge e Iaiá. Dessa forma, os excertos da narrativa homérica são recombinados por Machado para delinear a circunstância emocional de Iaiá Garcia.

${ }^{10}$ Diomedes. 
Uma vez mais a metáfora do amor como guerra se concretiza na relação entre os pares similares possíveis de confrontamento por meio da comparação intertextual: Diomedes/ Jorge, Diomedes/Estela, Iaiá/Vênus. Além disso, Machado aproveita para pôr em evidência na narrativa, por meio do narrador onisciente, o tema que agita a parte final do romance: a rivalidade entre as duas personagens femininas, em que os ecos do mito do julgamento de Páris (quem é a mais bela entre as duas?) se faz notar. Ainda que Jorge não desempenhe no enredo o papel de Páris, na medida em que não lhe é permitido escolher entre as divas, Iaiá e Estela sentem-se ambas cobradas por este pesado julgamento patriarcal, de que é prova a rivalidade silenciosa que acabam desenvolvendo entre si.

\section{Adentrando a fábrica de Menipo}

Homero não deixará de ser emulado por Machado em nenhum de seus romances seguintes, das Memórias Póstumas ao Memorial de Aires. A forma de emular, entretanto, se modificará a partir de sua filiação à tradição da sátira menipeia. Não por acaso, as referências a Luciano de Samósata e ao Sêneca satírico, inexistentes nos romances aqui analisados, aparecerão pela primeira vez em seus escritos do início da década de 1880: Memórias Póstumas e no conto Teoria do Medalhão, presente em Papéis Avulsos. Dessa forma, os diálogos machadianos com Homero que aqui percorri, limitados ao corpus selecionado, devem ser tomados, assim proponho, como um percurso de leitura de e sobre Machado em face dos clássicos antigos, ponto sobre os quais voltarei a falar em outros momentos. ${ }^{11}$

\section{REFERÊNCIAS}

ASSIS, J. M. M. de. História de 15 dias. In: . Obra completa. Rio de Janeiro: Nova Aguilar, 2006b. v. 3, p. 357-58.

ASSIS, J.M. M. de. Notícia da atual literatura brasileira - Instinto de nacionalidade. In:

Obra completa. Rio de Janeiro: Nova Aguilar, 2006b. v. 3, p. 803-9.

ASSIS, J. M. M. de. Obra completa. Rio de Janeiro: Nova Aguilar, 2006a. v. 1.

BAKHTIN, M. O discurso em Dostoiévski. In: . Problemas da poética de Dostoievski. Rio de Janeiro: Forense Universitária, 2002, p. 157-238.

BOSI, A. Machado de Assis: cadeira 23, ocupante 1 (fundador). Rio de Janeiro: Academia Brasileira de Letras; São Paulo: Imprensa oficial do Estado, 2011.

\footnotetext{
${ }^{11}$ No próximo quadriênio (2020-2023), pretendo percorrer os cinco outros romances publicados por Machado, no âmbito do projeto Reminiscências da cultura clássica na obra de Machado de Assis, que coordeno no Programa de Pós-Graduação em Letras da Universidade Federal de Viçosa.
} 
BRANDÃO, J. L. A Grécia de Machado de Assis. In: MENDES, E. A de M.; OLIVEIRA, P. M.; BENN-IBLER, V. O novo milênio: interfaces lingüísticas e literárias. Belo Horizonte: Faculdade de Letras da UFMG, 2001, p. 351-74.

BRANDÃO, J. L. Antiga Musa: arqueologia da ficção. 2 ed. Belo Horizonte: Relicário, 2015.

COELHO, M. C. de M. N. Helena, Eurípides e Machado de Assis. Espelho, n. 8/9, p. 37-61, 2002.

FIORIN, J. L. Introdução ao pensamento de Bakhtin. São Paulo: Ática, 2008.

GRIMAL, P. Dicionário da mitologia grega e romana. 5 ed. Rio de Janeiro: Bertrand Brasil, 2005.

GUIMARÃES, H. S. Os leitores de Machado de Assis: o romance machadiano e o público de literatura no século 19. São Paulo: Nankin: Edusp, 2012, p. 135-58.

HOMERO. Ilíada. Tradução de Carlos Alberto Nunes. Rio de Janeiro: Nova Fronteira, 2011.

HOMERO. Odisseia. Tradução de Manoel Odorico Mendes. Edição e revisão de Teotonio Simões. [S.l.]: Ebooks Brasil, 2009b. E-book. Digitalizado e editado a partir da 3. ed. da Biblioteca Clássica, da Atena Editora. Disponível em:

http://www.ebooksbrasil.org/adobeebook/odisseiap.pdf. Acesso em: 25 jan. 2020.

MALTA, A. Morte e vida de Homero: três visões do poeta grego publicadas no século XVIII. Revista USP, n. 94, p. 166-75, 2012.

MARTINS, E. F. Afrodite nos trópicos: a reescrita da cultura clássica no romance $A$ mão e a luva, de Machado de Assis. Rónai, v. 3, n. 2, p. 37-62, 2015.

MASSA, J-M. A biblioteca de Machado de Assis. In: JOBIM, José Luís (org.). A biblioteca de Machado de Assis. Rio de Janeiro: Topbooks, 2001, p. 21-97.

MEYER, A. De Machadinho a Brás Cubas. Teresa, v. 6-7, p. 409-17, 2006.

REGO, E. de S. Machado de Assis, a sátira menipéia e a tradição luciânica. Rio de Janeiro: Forense Universitária, 1989.

ROCHA, J. C. de C. Machado de Assis: por uma poética da emulação. Rio de Janeiro: Civilização Brasileira, 2013.

VIRGílLIO. Eneida. Trad.: Manuel Odorico Mendes. Paris: Typographia de Rignoux, 1854. Versão digitada da Eneida Brazileira por Leandro Abel Vendemiatti e revisada por Paulo Sérgio de Vasconcellos. Disponível em: http://www.unicamp.br/iel/projetos/OdoricoMendes/. 